\title{
The Effect of Coronavirus on the Sustainability of Public Company and Its Financial Performance
}

\author{
(Study of The Company is listed on the Indonesian Stock Exchange) \\ Dadang Purwo Ari Widodo*, Zenita Afifah Fitriyani, Devi Iriandha Widyastuti \\ Economic Faculty \\ University of Mayjend Sungkono \\ Mojokerto, Indonesian \\ *dadankariew@gmail.com, zenitaafifah@gmail.com, deviiriandhaw@gmail.com
}

\begin{abstract}
Coronavirus Disease 2019 (COVID-19) has a significant impact on all sectors in Indonesia. Especially for the sustainability of today's business world, because sustainability is an important issue that has the potential to affect company performance. This condition is increasingly visible in the domestic economy, especially on the corporate side. Deteriorating economic activity and business activities spread to the financial sector, due to the impact of the domestic economic and financial crisis, resulting in financial instability and economic recession. The government provides a stimulus budget for industrial support of IDR 75 trillion which is expected to support the national economic recovery program, so companies need to implement corporate sustainability to improve financial performance and provide confidence for investors because company sustainability is proof that the company has good management. The purpose of this study is to analyze the impact of the coronavirus on the sustainability of the financial performance of public companies listed on the Indonesian Stock Exchange. The method used in data analysis is a descriptive statistical analysis to provide a statistical description of the variables. The population in this study are all manufacturing companies listed on the Indonesian Stock Exchange, the sample selection uses purpose sampling with the criteria for companies listed on the Indonesian Stock Exchange during 2019 which report audited financial reports in 2019 and which report unaudited financial reports up to Quarter III of the year. 2020. Companies that lose money are omitted in the sample. Tests are carried out using multiple linear regression models with the dependent variable being the sustainable growth rate and the independent variables being company size, profitability, leverage, and operating efficiency.
\end{abstract}

Keywords-component, coronavirus, sustainability, business, financial performance, public company

\section{INTRODUCTION}

On March 12, 2020, WHO announced the coronavirus or Covid-19 as a pandemic caused by Severe Acute Respiratory Syndrome Coronavirus 2 (SARS-COV-2), where Covid-19 has a major impact on the world economy [1]. The Covid-19 outbreak raises concerns about the future of the business world because it is feared that it could worsen economics, business, and human conditions [2]. So that during this pandemic, companies must be careful in seeing opportunities, so that they can continue to improve their business capabilities [3].

The spread of the coronavirus in Indonesia has increased significantly. Currently, 236,519 people have been infected with the Coronavirus in Indonesia and 170,774 people have been declared cured and 9,336 people have died [4]. Coronavirus brought major changes that affected the company's business activities [5]. The decline in economic and business activities has spread to the financial sector. This is due to the spread of the coronavirus that is spreading and the slowing pace of the domestic economy [6]. Judging from the statistical data of PT. Indonesian Stock Exchange (IDX), JCI has dropped $13.44 \%$ from January 1 to February 28, 2020 (year to date). Data on the Jakarta Interbank Spot Dollar rate (JISDOR) reference rate from Bank Indonesia (BI) as of 15 September 2020 shows that the Rupiah was corrected at 14,870 per USD. Since January 2, 2020, from a level of IDR 13,895 per USD. So that it can be seen that the impact of the coronavirus can affect the sustainability of a company [7].

Pastor and Vorsatz [8] found investors views on investment decisions, namely by looking at several factors that can affect firm value, such as company size, profitability, leverage and operating efficiency. So, the purpose of this study is to analyze the impact of the coronavirus on the sustainability of the financial performance of public companies listed on the Indonesia Stock Exchange.

\section{LITERATURE REVIEW}

\section{A. Coronavirus in Indonesian}

The corona pandemic that has plagued ASEAN countries, including Indonesia has hurt all economic activities. The implementation of lockdown and quarantine makes people able to stay at home. In addition, business activities must be stopped to avoid crowds and prevent the spread of viruses [9]. Company leaders admit that they are going through difficult 
times due to the coronaviruses. They are trying to retain employees amidst these difficulties even though the company's financial condition is declining [10].

The impact of the coronavirus in Indonesia has also resulted in an economic crisis. This cannot be allowed to drag on, because it can cause long-term weakening of financial conditions [11]. In planning the financial performance of public companies in Indonesia, it is necessary to pay attention to risk management, to adapt to changing conditions, so that business sustainability is maintained [12].

\section{B. Business Sustainability and Sustainability Growth Rate}

Sustainability can motivate shareholders in the long term to determine the business, take opportunities, and manage risks arising from social, environmental, and economic factors. Sustainability behaviour can add value, provide a capability, and effectiveness in enhancing the company's image [13]. The sustainability business model (SBM) is expected to provide social, environmental and economic benefits simultaneously. Many strategies can be proposed in implementing the principles of sustainability, one of which is by improving the company's financial performance [14].

In financial management, business continuity has the goal of maximizing shareholder wealth. Smith's theory leads to constant growth and development is not limited by limited resources. Financial management focuses on sustainable financial performance to increase the company's ability, so it is necessary to adjust the company size, profitability, leverage, and operating efficiency of the company [15].

\section{Company Size, Profitability, Leverage, and Operating Efficiency}

Based on the assets owned by the company, it can be seen how big the size is. Because large companies with more complex management have higher profits than small companies. Large companies with dense activity and high profits, have to pay higher taxes as well. Therefore, the size of the company has a relationship with the value issued [16]. A company is considered good if it benefits from all aspect of its activities. Besides, the more income earned and the better the manager's ability to control the company's capital, that more the company size increases [17].

Profitability is the company's ability to generate profits, high profits indicate good company performance, thus encouraging the company to be able to complete financial performance reports on time [18]. Therefore, companies that can adapt quickly to changing circumstances are those that have a beneficial effect on profitability [19].

Leverage is a ratio that measures the size of the company using debt financing. High leverage can change the company's policy in converting future income to current income because the use of leverage on debt can increase company value [20]
Many large companies believe that a large market with well-differentiated products can increase profitability, further increasing their operational efficiency [21].

\section{Methodology}

\section{A. Sample Selection}

The population used in this study is pulp and paper companies in Indonesia that have to go public on the Indonesia Stock Exchange. The samples used in this study were pulp and paper companies listed on the Indonesia Stock Exchange up to 2019, Companies that posted net income in 2019, The company posted a net profit for the second quarter of 2020, Companies that have audited 2019 financial statements, Companies that have presented interim financial reports up to the second quarter of 2020 or Interim financial reports (unaudited) as of June 2020. See table 1 below.

TABLE I. The COMPANY Went PUBLIC IN THE PUlP AND PAPER SECTOR FOR THE PERIOD 2019 - 2020

\begin{tabular}{|l|l|l|}
\hline No. & \multicolumn{1}{|c|}{ Criteria } & amount \\
\hline 1 & $\begin{array}{l}\text { Pulp and paper companies that have } \\
\text { gone public are listed on the IDX for the } \\
\text { 2019-2020 period } \\
\text { Companies that suffered losses in 2019 } \\
3\end{array}$ & $\begin{array}{l}\text { Companies that suffered losses in the } \\
\text { second quarter of 2020 } \\
\text { Companies that do not report financial } \\
\text { statements (audited) for 2019. } \\
\text { Companies that do not present interim } \\
\text { financial reports for the second quarter } \\
\text { of 2020 } \\
\text { The number of research samples } \\
\text { The total sample of observations 6x2 } \\
\text { Financial statements }\end{array}$ \\
\hline
\end{tabular}

Source: www.idx.co.id

The go public companies in the pulp and paper sector on the IDX which were the research samples were as follows on table 2:

TABLE II. LIST OF COMPANIES USED AS RESEARCH SAMPLES

\begin{tabular}{|l|l|l|}
\hline No. & Company Code & \multicolumn{1}{c|}{ Company name } \\
\hline 1 & ALDO & Alkindo Naratama Tbk \\
\hline 2 & FASW & Fajar Surya Wisesa Tbk \\
\hline 3 & INKP & Indah Kiat Pulp \& Paper Tbk \\
\hline 4 & KDSI & Kedawung Setia Industrial Tbk \\
\hline 5 & SPMA & Suparma Tbk \\
\hline 6 & TKIM & Tjiwi Kimia Paper Factory Tbk \\
\hline
\end{tabular}

Source:www.idx.co.id

\section{B. Variable Definition and Measurement}

In this study, the variables used are independent variables which are variables that affect other variables, while the independent variables used are company size, leverage, profitability and operating efficiency. The dependent variable is a variable that is influenced by other independent variables, and in this study the variable in question is sustainability. See table 3 below. 
TABLE III. VARIABLE MEASUREMENT

\begin{tabular}{|c|c|c|c|}
\hline Variable & Notation & Measurement & $\begin{array}{c}\text { Previous } \\
\text { Work }\end{array}$ \\
\hline $\begin{array}{l}\text { Sustainability } \\
\text { (Y) }\end{array}$ & SGR & $\begin{array}{l}\text { SGR }=\text { ROE }(1-\text { DPR }) \\
\text { ROE }=\text { Return on Equity } \\
\text { DPR }=\text { Devident Payout }\end{array}$ & {$[1][2]$} \\
\hline $\begin{array}{l}\text { Company } \\
\text { Size (X1) }\end{array}$ & FS & $\begin{array}{l}\text { Ratio } \\
\text { Ln of Total Asset }\end{array}$ & $\begin{array}{l}{[3][4][5][6][2]} \\
{[7][8][1][8]} \\
{[7][5][9][10]}\end{array}$ \\
\hline $\begin{array}{l}\text { Leverage } \\
\text { (X2) }\end{array}$ & DAR & Total Debt / Total Asset & {$[11][10]$} \\
\hline $\begin{array}{l}\text { Profitability } \\
\text { (X3) }\end{array}$ & ROA & Net Income / Total Asset & \\
\hline $\begin{array}{l}\text { Operating } \\
\text { Efficiency } \\
\text { (X4) }\end{array}$ & BOPO & $\begin{array}{l}\text { Operating Expenses } \\
\text { Operating Income }\end{array}$ & \\
\hline
\end{tabular}

\section{RESULTS AND DISCUSSION}

\section{A. Conceptual Framework}

See figure 1 below.

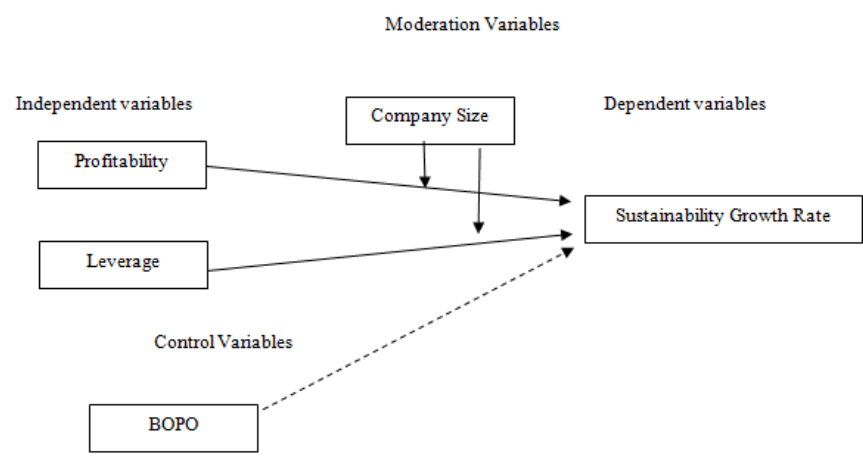

Fig. 1. Conceptual framework.

\section{B. Descriptive Statistics}

See table 4 below.

TABLE IV. DESCRIPTIVE STATISTICS

\begin{tabular}{|l|l|l|l|l|l|}
\hline & $\mathbf{N}$ & \multicolumn{1}{|c|}{ Min } & \multicolumn{1}{|c|}{ Max } & \multicolumn{1}{|c|}{ Mean } & $\begin{array}{c}\text { Std. } \\
\text { Deviation }\end{array}$ \\
\hline TWO & 12 & .03 & .09 & .0542 & 0.1676 \\
\hline Leverage & 12 & .39 & .60 & .4925 & .06904 \\
\hline BOPO & 12 & .32 & .76 & .5250 & .13338 \\
\hline Company Size & 12 & 27.55 & 32.43 & 29.6283 & 1.89933 \\
\hline Sustainability & 12 & .06 & .15 & .1067 & .02570 \\
\hline Valid N (lustwise) & 12 & & & & \\
\hline
\end{tabular}

The minimum value of the profitability variable projected with Return On Asset (ROA) is 0.03 the maximum value is 0.09 with an average value of 0.054 and a standard deviation of 0.016. This indicates that the average capability of the company in generating profit from the total assets used is 5.42 percent.

The minimum value of the leverage variable is 0.39 the maximum value of 0.60 with an average value of 0.492 and a standard deviation of 0.069 . This reflects that the average debt of a company financed by debt is 49.2 percent

The minimum value of BOPO is 0.32 maximum value 0.76 with an average value of 0.525 and a standard deviation of 0.133 . This illustrates that the average level of efficiency of a company in managing the company's finances is seen from operating costs compared to operating income of 52.5 percent

The minimum value of Company Size is 27.55 maximum value of 32.43 with an average value of 29.62 and a standard deviation of 1,899 . This indicates that the average natural logarithmic value of the total assets owned by the company is 29.62 percent.

The minimum sustainability value projected with Sustainability Growth Rate (SGR) is 0.06 the maximum value is 0.15 with an average value of 0.106 and a standard deviation of 0.025 . This indicates that the average capability of the company in generating profit from the total assets used is 5.42 percent.

\section{Normality Test}

The normality test is used to test whether in a regression model, the bound variable and the independent variable or both have a normal distribution or not. A good regression model is normal or near-normal data distribution. The data is said to be distributed normally if the significance of Asymp. Sig is greater than> 0.05. The results of the Kolmogorov-Smirnov test can be seen in table 5 .

TABLE V. NORMALITY TEST

\begin{tabular}{|l|l|l|}
\hline \multicolumn{2}{|c|}{} & \multicolumn{1}{|c|}{$\begin{array}{c}\text { Unstandardized } \\
\text { Residual }\end{array}$} \\
\hline $\mathrm{N}$ & Mean & 12 \\
\cline { 2 - 3 } Normal Parameters, ${ }^{\mathrm{b}}$ & Std. Deviation & .0000000 \\
\hline \multirow{2}{*}{ Most Extreme Differences } & Absolute & .00699745 \\
\cline { 2 - 3 } & Positive & .178 \\
\cline { 2 - 3 } & Negative & .178 \\
\hline Test Statistic & -.093 \\
\hline Asymp.Sig (2-tailed) & .178 \\
\hline \multicolumn{2}{|c|}{} & $.200^{\text {c,d }}$ \\
\hline \multicolumn{2}{|c|}{ a. Test distribution is Normal. } \\
\multicolumn{2}{|c}{ b. Calculated from data. } \\
c. Lilliefors Significance Correction.
\end{tabular}

d. This is a lower bound of the true significance.

From the results of the Kolmogorov-Smirnov test in the table above that, the data tested are normally distributed due to Asymp values. Sig (2-tailed) of 0,200>0.05 Thus the table above can be concluded that the regression model meets the assumption of normality.

\section{Multicolineineity Test}

This test aims to detect the existence of multicollinearity problems, so it can be done by looking at the value of tolerance and variance inflation factor (VIF). Multicolineoline does not occur when the tolerance value is large $>0.1$ and the VIF value is small $<10$. See table 6 below. 
TABLE VI. MULTICOLINEARITY TEST

\begin{tabular}{|c|c|c|c|c|c|c|c|c|}
\hline \multirow{2}{*}{\multicolumn{2}{|c|}{ Model }} & \multicolumn{2}{|c|}{$\begin{array}{l}\text { Unstandardized } \\
\text { Coefficients }\end{array}$} & \multirow{2}{*}{$\begin{array}{c}\text { Standardized Coefficients } \\
\text { Beta } \\
\end{array}$} & \multirow[t]{2}{*}{$\mathbf{t}$} & \multirow[t]{2}{*}{ Sig. } & \multicolumn{2}{|c|}{ Collinearity Statistics } \\
\hline & & $B$ & Std.Error & & & & Tolerance & VIF \\
\hline \multirow[t]{5}{*}{1} & (Constant) & -.060 & .062 & & -.972 & .363 & & \\
\hline & TWO & 1,562 & .180 & 1,019 & 8,679 & .000 & .769 & 1,301 \\
\hline & Leverage & .095 & .048 & .255 & 1,991 & .087 & .644 & 1,554 \\
\hline & BOPO & .051 & .024 & .263 & 2,090 & .075 & .667 & 1,498 \\
\hline & Company Size & .000 & .002 & .023 & .153 & .883 & .481 & 2,078 \\
\hline
\end{tabular}

a. Dependent Variable: Sustainability

Based on the table above it can be seen that the value of tolerance has a value of more than> 0.1 and the value of variance inflation factor (VIF) also shows a value of $<10$, so it can be stated that the regression model is independent of multicolineineity used in this study.

\section{E. Autocorrelation Test}

This test is performed to test whether in linear regression the correlation between user error in period $t$ and error in period $\mathrm{t}-1$. To detect the presence of autocorrelation in the regression model can be done using the Durbin-Watson (DW) test. If the number in the Durbin-Watson (DW) test is between -2 to 2 then there is no autocorrelation. See table 7 below.

TABLE VII. AUTOCORRELATION TEST

\begin{tabular}{|c|c|l|l|l|l|}
\hline $\begin{array}{c}\text { Mode } \\
\mathbf{1}\end{array}$ & $\mathbf{R}$ & R Square & $\begin{array}{c}\text { Adjusted } \\
\text { R Square }\end{array}$ & $\begin{array}{c}\text { Std. } \\
\text { Error of } \\
\text { the } \\
\text { Estimate }\end{array}$ & $\begin{array}{c}\text { Durbin- } \\
\text { Watson }\end{array}$ \\
\hline 1 & $.962^{\mathrm{a}}$ & .926 & .884 & .00877 & 1,196 \\
\hline
\end{tabular}

a. Predictors: (Constant), Company Size, ROA, BOPO, Leverage

b. Dependent Variable: Sustainability

Based on the table above it can be seen that the autocorrelation test results show a DW value of 1,196 whose value lies between 22 to 2 , so it can be concluded that the regression model does not occur autocorrelation.

\section{F. Heteroscedasticity Test}

The heteroscedasticity test aims to test whether in a regression model there is an inequality of variance from residual to one observation. If the variance from residual one observation to another observation remains, then homozygocity occurs and if different then it is called heteroscedasticity. The detection of a regression model independent of heteroscedasticity is if the probability value is greater> 0.05 . See table 8 below.
TABLE VIII. HETEROSCEDASTICITY TEST

\begin{tabular}{|c|c|c|c|c|c|c|}
\hline & \multirow[t]{2}{*}{ Model } & \multicolumn{2}{|c|}{$\begin{array}{l}\text { Unstandardized } \\
\text { Coefficients }\end{array}$} & $\begin{array}{c}\text { Standardized } \\
\text { Coefficients }\end{array}$ & \multirow[t]{2}{*}{$\mathbf{t}$} & \multirow[t]{2}{*}{ Sig. } \\
\hline & & $B$ & Std.Error & Beta & & \\
\hline \multirow[t]{5}{*}{1} & (Constant) & .029 & .019 & & 1,522 & .172 \\
\hline & TWO & .078 & .054 & .351 & 1,433 & .195 \\
\hline & Leverage & -.005 & .014 & -.099 & -.368 & .724 \\
\hline & BOPO & -.017 & .007 & -.627 & $-2,383$ & .049 \\
\hline & $\begin{array}{l}\text { Company } \\
\text { Size }\end{array}$ & -.001 & .001 & -.265 & -.854 & .421 \\
\hline
\end{tabular}

Based on the results of the heterokedness test using the glejser test, a sig value can be obtained. greater> 0.05 then it can be concluded that there is no heterokedasity.

\section{G. Hypothesis Test}

Hypothesis testing in this study uses moderated regression analysis (MRA) or interaction test due to the presence of company size variables that become moderation variables. Moderated regression analysis (MRA) is a special application of linear multiple regression in which the regression equation contains an element of interaction.

$\mathrm{Y}=\alpha+\beta 1 \mathrm{X} 1+\beta 2 \mathrm{X} 2+\beta 3 \mathrm{Z}+\beta 4(\mathrm{X} 1 * \mathrm{Z})+\beta 5(\mathrm{X} 2 * \mathrm{Z})+\varepsilon$

Where:

$\mathrm{Y}=$ Sustainability Growth Rate

$\alpha=$ Constant

$\beta 1,-\beta 5=$ Regression Coefficient

$\mathrm{X} 1$ = Profitability (independent variable)

X2 = Leverage (independent variable)

$\mathrm{Z}=$ Company Size (moderation variable)

$\mathrm{X} * \mathrm{Z}=$ Interaction between independent variables and moderation variables study

$\varepsilon=$ Error term, which is the level of predictive error in the

\section{H. The First Hypothesis}

Whether profitability, in this case, is projected with return on assets (ROA) affects sustainability Growth Rate. See table 9 below. 
TABLE IX $\quad$ The RESUlts of SimPle REgRESSION ANALysis

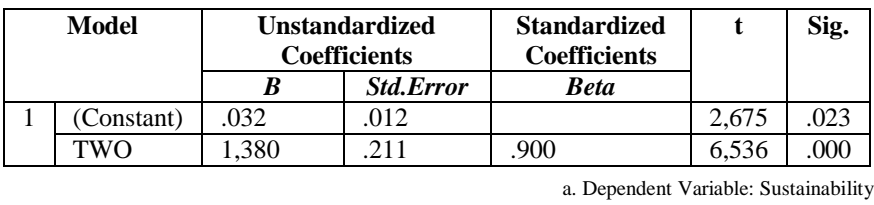

The results of the first hypothesis analysis showed that the profitability calculation (ROA) was 6,536 with a significance level of less than $0,000<0.005$ and a regression coefficient of 1,380. This means that profitability has a positive and significant relationship to sustainability.

The regression equation of the first model above obtained the equation, see table 10 below:

TABLE X. DETERMINATION COEFFICIENT (R2)

\begin{tabular}{|c|c|l|l|l|}
\hline Mode 1 & R & R Square & $\begin{array}{l}\text { Adjusted } \\
\text { R Square }\end{array}$ & $\begin{array}{c}\text { Std. Error of the } \\
\text { Estimate }\end{array}$ \\
\hline 1 & $.900 \mathrm{a}$ & .810 & .791 & .01174 \\
\hline
\end{tabular}

a. Predictors: (Constant), ROA

The adjusted $\mathrm{R}$ square figure indicates the coefficient of determination or the role of variance (independent variable to the dependent variable). The adjusted $\mathrm{R}$ square number of 0.791 shows that only $79.1 \%$ of dependent variables can be explained by independent variables, the remaining $20.9 \%$ is explained by other factors.

\section{The Second Hypothesis}

Does leverage affect the sustainability Growth Rate. See table 11 below.

TABLE XI. The RESUlts OF SIMPLE REGRESSION ANALYSIS

\begin{tabular}{|c|l|l|l|l|l|l|}
\hline \multicolumn{2}{|c|}{ Model } & \multicolumn{2}{|c|}{$\begin{array}{c}\text { Unstandardized } \\
\text { Coefficients }\end{array}$} & $\begin{array}{c}\text { Standardized } \\
\text { Coefficients }\end{array}$ & \multirow{2}{*}{ Sig. } & \\
\cline { 3 - 7 } \multicolumn{2}{|c|}{} & $\boldsymbol{B}$ & Std.Error & Beta & & \\
\hline \multirow{2}{*}{1} & (Constant) & .087 & .058 & & 1,495 & .166 \\
\cline { 2 - 7 } & Leverage & .040 & .117 & .108 & .342 & .739 \\
\hline
\end{tabular}

a. Dependent Variable: Sustainability

The results of the second hypothesis analysis showed that the calculation of laverage was 0.432 with a significance level of 0.739 greater $>0.005$ and a regression coefficient of 0.04 . This means that laverage has no positive and significant relationship to sustainability. Or the laverage variable does not affect sustainability

The regression equation of the second model above obtained the equation: $\mathrm{Y}=0.087+0.04 \mathrm{X} 2+\varepsilon$

\section{J. The Third Hypothesis}

Whether the firm measures the influence of profitability (ROA) on Sustainability Growth Rate. See table 12 below.
TABLE XII. MODERATE VARIABLE REgRESSION RESUlTS

\begin{tabular}{|c|l|l|l|l|l|l|}
\hline \multicolumn{2}{|c|}{ Model } & \multicolumn{2}{|c|}{$\begin{array}{c}\text { Unstandardized } \\
\text { Coefficients }\end{array}$} & $\begin{array}{c}\text { Standardized } \\
\text { Coefficients }\end{array}$ & \multirow{2}{*}{ Sig. } & \\
\cline { 2 - 7 } \multicolumn{2}{c|}{} & $\boldsymbol{B}$ & Std.Error & Beta & & \\
\hline \multirow{2}{*}{1} & (Constant) & .031 & .013 & & 2,436 & .038 \\
\cline { 2 - 7 } & TWO & .957 & 1,119 & .624 & .855 & .414 \\
\cline { 2 - 7 } & XIZ & .015 & .039 & .282 & .386 & .709 \\
\hline
\end{tabular}

The results of the second hypothesis analysis show that $\mathrm{X} 1 \mathrm{Z}$ has a significance level of 0.709 greater $>0.005$. This means that the firm size variable is not a moderate variable or with the other assumption that the profitability variable interacted through the firm size variable does not affect sustainability.

The regression equation of the third model above obtained the equation:

$$
\mathrm{Y}=0.031+0.957 \mathrm{X} 1+0.015(\mathrm{X} 1 * \mathrm{Z})+\varepsilon
$$

TABLE XIII. The Result OF THE DETERMINATION COEFFICIENT (R2) WITH THE MODERATION VARIABLE

\begin{tabular}{|c|c|l|l|l|}
\hline Mode 1 & R & R Square & $\begin{array}{l}\text { Adjusted } \\
\text { R Square }\end{array}$ & $\begin{array}{c}\text { Std. Error of the } \\
\text { Estimate }\end{array}$ \\
\hline 1 & $.902 \mathrm{a}$ & .813 & .772 & .01227 \\
\hline
\end{tabular}

The adjusted $\mathrm{R}$ square figure indicates the coefficient of determination or the role of variance (independent variable in relation to the dependent variable). From table 6 can be seen the decrease in the value of adjusted $\mathrm{R}$ square from the first regression model to the third regression model by $1.9 \%$ (adjusted R square in the first regression model by $79.1 \%$ ). The adjusted $\mathrm{R}$ square figure of 0.772 shows that only $77.2 \%$ of the sustainability variable can be explained by the profitability variable (ROA) moderated by the size of the company, the remaining $22.8 \%$ is explained by other factors.

\section{K. The Fourth Hypothesis}

Does the size of the firm strengthen the effect of leverage on Sustainability Growth Rate. See table 14 below.

TABLE XIV. MODERATE VARIABLE REgRESSION RESUlTS

\begin{tabular}{|c|c|c|c|c|c|c|}
\hline \multirow{2}{*}{\multicolumn{2}{|c|}{ Model }} & \multicolumn{2}{|c|}{$\begin{array}{c}\text { Unstandardized } \\
\text { Coefficients }\end{array}$} & $\begin{array}{c}\text { Standardized } \\
\text { Coefficients }\end{array}$ & \multirow[t]{2}{*}{$\mathbf{t}$} & \multirow[t]{2}{*}{ Sig. } \\
\hline & & B & Std.Error & Beta & & \\
\hline \multirow[t]{3}{*}{1} & (Constant) & .056 & .069 & & .807 & .440 \\
\hline & Leverage & .373 & .401 & 1,003 & .932 & .376 \\
\hline & $\mathrm{X} 2 \mathrm{Z}$ & -.009 & .010 & -.937 & -.871 & .406 \\
\hline
\end{tabular}

The results of the second hypothesis analysis show that $\mathrm{X} 2 \mathrm{Z}$ has a significance level of 0.406 greater than $>0.005$. This means that the firm size variable is not a moderate variable or with the other assumption that the leverage variable interacted through the firm size variable has no effect on sustainability. 
The regression equation of the fourth model above obtained the equation:

$$
\mathrm{Y}=0.056+0.373 \mathrm{X} 2-0.009(\mathrm{X} 2 * \mathrm{Z})+\varepsilon
$$

\section{The Fifth Hypothesis}

Whether profitability and leverage simultaneously affect sustainability. See table 15 and 16 below.

TABLE XV. F TEST

\begin{tabular}{|c|l|l|l|l|l|c|}
\hline \multicolumn{2}{|c|}{ Model } & $\begin{array}{c}\text { Sum of } \\
\text { Squares }\end{array}$ & df & $\begin{array}{c}\text { Mean } \\
\text { Square }\end{array}$ & F & Sig. \\
\hline \multirow{2}{*}{1} & Regression & .006 & 2 & .003 & 29,456 & $.000 \mathrm{~b}$ \\
\cline { 2 - 7 } & Residual & .001 & 9 & .000 & & \\
\cline { 2 - 7 } & Total & .007 & 11 & & & \\
\hline
\end{tabular}

a. Dependent Variable: Sustainability

b. Predictors: (Constant), ROA, Leverage

TABLE XVI. The Results of Multiple Regression Test AnAlysis

\begin{tabular}{|c|l|l|l|l|c|c|}
\hline \multirow{2}{*}{ Model } & \multicolumn{2}{|c|}{$\begin{array}{c}\text { Unstandardized } \\
\text { Coefficients }\end{array}$} & \multicolumn{2}{c|}{$\begin{array}{c}\text { Standardized } \\
\text { Coefficients }\end{array}$} & t & Sig. \\
\cline { 2 - 5 } \multicolumn{2}{c|}{} & B & Std.Error & Beta & & \\
\hline \multirow{2}{*}{1} & (Constant) & -.015 & .026 & & -.584 & .574 \\
\cline { 2 - 7 } & Leverage & .090 & .046 & .242 & 1,970 & .080 \\
\cline { 2 - 7 } & TWO & 1,433 & .188 & .935 & 7,624 & .000 \\
\hline
\end{tabular}

a. Dependent Variable: Sustainability

The results of the fifth hypothesis analysis show in table 12 profitability (ROA) and leverage simultaneously affect sustainability with a significance level of less than 0,000 $<0.005$, This means that profitability and leverage together have a negative and significant relationship to sustainability.

The regression equation of the fifth model above obtained the equation: $\mathrm{Y}=-0.015+0.09 \mathrm{X} 1+1,433 \mathrm{X} 2+\varepsilon$

TABLE XVII. DETERMINATION COEFFICIENT (R2)

\begin{tabular}{|c|c|c|c|c|}
\hline Model & R & R Square & $\begin{array}{c}\text { Adjusted R } \\
\text { Square }\end{array}$ & $\begin{array}{c}\text { Std. Error of } \\
\text { the Estimate }\end{array}$ \\
\hline 1 & $.931 \mathrm{a}$ & & & \\
\hline
\end{tabular}

a. Predictors: (Constant), ROA, Leverage

The adjusted $\mathrm{R}$ square figure indicates the coefficient of determination or the role of variance (independent variable in relation to the dependent variable). The adjusted $\mathrm{R}$ square figure of 0.838 shows that only $83.8 \%$ of the sustainability variables can be explained by profitability and leverage, the rest $16.2 \%$ is explained by other factors.

\section{CONCLUSION}

The results of this study conclude that company size and leverage have a negative effect on sustainability while operating efficiency and profitability have a positive effect on sustainability. Profitability has a very significant effect on sustainability, so maximizing the use of assets to achieve or increase the company's net profit greatly affects the sustainability of pulp and paper companies during the crisis or pandemic Covid-19 disaster. This research also shows that the resilience of pulp and paper companies in Indonesia in maintaining sustainability during the crisis or the COVID - 19 pandemic disaster was still very low, only $6.67 \%$. The limitation of this study is that it only uses a sample of pulp and paper companies. Suggestions for further research can examine company objects outside companies engaged in the pulp and paper industry, for example in the finance, food and beverage sector and others. Likewise, the use of models in measuring sustainability uses Van Horne's model, Higgen's model or Zakon's model.

\section{ACKNOWLEDGMENT}

We thank $\mathrm{Mr}$ Dr. HerySetiawan, S.H. M. Si as the chancellor of Mayjend Sungkono University, and we also thank Mr Dr. (cand). Doddy Syahirul Alam, S.E., M. Si who have provided motivation and suggestions for the paper we made.

\section{REFERENCES}

[1] M. Nicola et al., "The socio-economic implications of the coronavirus pandemic (COVID-19): A review," Int. J. Surg., vol. 78, no. March, pp. 185-193, 2020, doi: 10.1016/j.ijsu.2020.04.018.

[2] S.A. Zahra, "International entrepreneurship in the post Covid world," J. World Bus., no. August, p. 101143, 2020, doi: 10.1016/j.jwb.2020.101143.

[3] L.F. Dumitrasciuc, "Entrepreneurship Trends after the Coronavirus Pandemic," vol. XX, no. 1, pp. 613-617, 2020.

[4] I. Emerging, "Home» Info Infeksi Emerging Kementerian Kesehatan RI,” 2020. https://infeksiemerging.kemkes.go.id/ (accessed Sep. 23, 2020).

[5] H. Shen, M. Fu, H. Pan, Z. Yu, and Y. Chen, "The Impact of the COVID-19 Pandemic on Firm Performance," Emerg. Mark. Finance. Trade, vol. 56, no. 10, pp. 2213-2230, 2020, doi: 10.1080/1540496X.2020.1785863.

[6] BI, "Bank Indonesia Official Web Site - Bank Sentral Republik Indonesia," 2020. https://www.bi.go.id/id/Default.aspx (accessed Sep. 23, 2020).

[7] BEI, "PT Bursa Efek Indonesia," 2020. https://www.idx.co.id/ (accessed Sep. 23, 2020).

[8] L. Pastor and B. Vorsatz, "Mutual Fund Performance and Flows During the COVID-19 Crisis," SSRN Electron. J., 2020, doi: 10.2139/ssrn.3648302.

[9] ASEAN Policy Brief, "Economic Impact of Covid-19 Outbreak on ASEAN," Assoc. Southeast Asian Nations, no. April, pp. 1-17, 2020, [Online]. Available: https://asean.org/storage/2020/04/ASEAN-PolicyBrief-April-2020_FINAL.pdf.

[10] A. Tarki, P. Levy, and J. Weiss, "The Coronavirus Crisis Doesn ' t Have to Lead to Layoffs," Harvard Bus. Rev. Digit., 2020, [Online]. Available: https://hbr.org/2020/03/the-coronavirus-crisis-doesnt-haveto-lead-to-layoffs.

[11] L. Hertati, M. Widiyanti, D. Desfitrina, A. Syafarudin, and O. Safkaur, "the Effects of Economic Crisis on Business Finance," Int. J. Econ. Finance. Issues, vol. 10, no. 3, pp. 236-244, 2020, doi: 10.32479/ijefi.9928.

[12] H. Karamoy and J. E. Tulung, "The effect of financial performance and corporate governance to stock price in non-bank financial industry," Corp. Ownersh. Control, vol. 17, no. 2, pp. 97-103, 2020, doi: 10.22495/cocv17i2art9. 
[13] P. Aggarwal, "Impact of Sustainability Performance of Company on its Financial Performance: A Study of Listed Indian Companies," Impact Sustain. Perform. Co. its Financ. Perform. A Study List. Indian Co., vol. 13, no. 11, 2013.

[14] S. Nosratabadi, G. Pinter, A. Mosavi, and S. Semperger, "Sustainable banking; Evaluation of the European business models," Sustain., vol. 12, no. 6, 2020, doi: 10.3390/su12062314.

[15] J. Xu and B. Wang, "Intellectual capital, financial performance and companies' sustainable growth: Evidence from the Korean manufacturing industry," Sustain., vol. 10, no. 12, 2018, doi: 10.3390/su10124651.

[16] G. Norman Thomas and L. Indriaty, "The Effect of Effective Tax Rates, Leverage, Litigation Costs, Company Size, Institutional Ownership, Public Ownership and the Effectiveness of Audit Committees in Accounting Conservatism at Public Companies LQ45," Talent Dev. Excell., vol. 12, no. 1s, pp. 85-91, 2020, [Online]. Available: http://www.iratde.com.

[17] A. Anwar and G. Gunawan, "Can Cash Holding, Bonus Plan, Company Size and Profitability Affect Income Smoothing Practices?,’ Point View
Res. Account. Audit., vol. 1, no. 3, pp. 49-56, 2020, doi: 10.47090/povraa.v1i3.35.

[18] L. Fujianti and I. Satria, "Firm size, profitability, leverage as determinants of audit report lag: Evidence from Indonesia," Int. J. Financ. Res., vol. 11, no. 2, 2020, doi: 10.5430/ijfr.v11n2p61.

[19] B. Vuković, S. Milutinović, V. Mirović, and N. Milićević, "The profitability analysis of the logistics industry companies in the balkan countries," Promet - Traffic - Traffico, vol. 32, no. 4, pp. 497-511, 2020, doi: $10.7307 /$ ptt.v32i4.3311.

[20] J. Lin, “A Review of Research on the Influencing Factors of China 's Corporation Debt Leverage Jiaming Lin PhD candidate School of Economics, Central University of Finance and Economics No . 39 South College Road, Haidian District, Beijing," vol. 11, no. 2, pp. 1-12, 2020, doi: 10.30845/ijbss.v11n2p1.

[21] J. Lotto, "Evaluation of factors influencing bank operating efficiency in the Tanzanian banking sector," Cogent Econ. Financ., vol. 7, no. 1, 2019, doi: 10.1080/23322039.2019.1664192. 